\title{
A New Framework for Education in Schools and the Link with Judicial Review
}

\author{
Fonathan Robinson *
}

Widespread interest in the law of education as it affects state-maintained schools is rapidly developing for two reasons. First, a political and controversial 'freemarket' philosophy underlies both recent and proposed legislation. The aims are to give power to parents and substantial independence to governing bodies of schools, while reducing the powers of the local education authority (LEA), changing the role of the latter from a 'provider' to that of an 'enabler', ' with the strong possibility of the eventual demise of LEAs. The Government's perspective is clear from the concluding chapter of its White Paper Choice and Diversity - $A$ new framework for schools (the ' 1992 White Paper'), ${ }^{2}$ which describes the proposals for legislation as " . . . the final stages of a great transformation in education which will take at least a decade to work through: a child tested at the age of 7 this year will not be taking [the General Certificate of Secondary Education] until 2001."3 These proposals purport to be given effect in the Education Bill 1992 (the '1992 Bill').

Secondly, the creation of an entirely new legislative framework, starting with the Education Act 1980, has led to a pronounced increase in the number of applications for judicial review, a trend which has been encouraged by the fact that a minor can be granted legal aid in his or her own right without reference to parental means. ${ }^{4}$

By contrast, a shortage of barristers and solicitors specialising in this area of law is a matter of concern but hardly surprising. In order to understand the legislation (especially subordinate) and the extensive flow of departmental circulars, a legal adviser must be familiar with teaching and administrative practice and the relationships between the Secretary of State and the Department for Education

* Senior Lecturer in Law, University of Buckingham and a Consultant Solicitor. This article is based on a paper which was given to the Education Law Association at the Institute of Education, London on November 30, 1992.

1. The Structure of Local Government in England (DES, April 1991), para. 19.

2. Cm. 2021, 1992.

3. Ibid., Ch. 15 , para. 1 .

4. Civil Legal Aid (General) Regulations 1989, reg. 16. 
(DFE), ${ }^{5}$ the LEA, school governors, teachers, pupils and parents.

This article aims to demonstrate the extent to which a relatively new specialism is influencing the development of administrative law in the context of education in schools in England and Wales and in particular the development of judicial review as a remedy in that context. The relevant legislation is considered as succinctly as accuracy permits, whereas the many issues (for example, the curriculum; financial matters; the roles of governing bodies, LEAs and the Secretary of State; admissions and exclusions; children's special educational needs; religious education) merit detailed examination. The 1992 White Paper is referred to as a source to explain current reform of the law of education in schools, as is the 1992 Bill. The final terms of the latter remain liable to substantial amendment, not least as to detail by the Government (probably as the Bill passes through the House of Lords). Even prior to publication of the Bill it was reported that Conservative education chairmen from both towns and counties were seeking major concessions from the Secretary of State. ${ }^{6}$

\section{THE GENERAL DUTY OF THE LEA}

Section 7 of the Education Act 1944 (the ' 1944 Act') requires the statutory system of public education to be organised in three progressive stages - primary, secondary and further education ${ }^{7}$ - and imposes a duty on the LEA, so far its powers extend "... to contribute towards the spiritual, moral, mental and physical development of the community by securing that efficient education throughout those stages shall be available to meet the needs of the population of their area."

The LEA's duty is more specifically set out in section $8(1)$, which requires LEAs to secure provision of primary and secondary schools for its area "... sufficient in number, character and equipment to afford for all pupils opportunities for education offering such variety of instruction and training as may be desirable in view of their different ages, abilities and aptitudes, and of the different periods for which they may be expected to remain at school, including practical instruction and training appropriate to their respective needs." There is also a duty to have regard inter alia to the need to secure that special educational provision is made for children who have special educational needs under the Education Act 1981.

Accordingly, the LEA maintains county schools (which are attended by approximately $75 \%$ of pupils in the state-maintained sector), special schools for children with special educational needs and voluntary schools (which usually have a denominational foundation). The Education Reform Act 1988 introduced grant-

5. Formerly the Department of Education \& Science (DES).

6. Sec, e.g., Education, Vol. 180 No. 13, pp. 241 et seq..

7. City Technology Colleges and Colleges for the Technology of the Arts are not 'maintained' Education Reform Act 1988, s. 105. 
maintained (GM) schools, which are outside LEA control and receive a grant from the DFE, equivalent to the sum which they would have received from the LEA, plus an addition to cover the services which are not provided by the LEA. ${ }^{8}$

Section 8 does not, however, impose an absolute duty on the LEA. In $R$. v. Surrey County Council Education Committee, ex parte $H,{ }^{9}$ Slade LJ in the Court of Appeal approved the proposition that "... there is no question of Parliament having placed the local authority under an obligation to provide a child with the best possible education. There is no duty on the authority to provide such a Utopian system, or to educate him or her to his or her maximum potential." The section has also been said only to impose a 'target' duty, with the effect that where an LEA fails without any fault on its part to comply for a limited period with the standard set by section 8 (for example, due to a shortage of teachers), it is not automatically in breach of the section. ${ }^{10}$

On the other hand, the Court of Appeal in R. v. Birmingham City Council, ex parte Equal Opportunities Commission (No. 2)" held that the LEA, in performing its duty under the 1944 Act, was also under a duty by virtue of section 23(1) of the Sex Discrimination Act 1975 not to discriminate on the ground of sex. While there is no unlawful sexual discrimination in the provision of places for boys and girls in selective secondary schools, the LEA when securing that sufficient schools are available for providing secondary education is obliged to take account of places which are available free. Neill LJ, giving the judgment of the court, stated that the relevant 'pool' of free places certainly included GM schools.

That judgment also emphasised that the Sex Discrimination Act 1975 and comparable legislation in the field of race relations ${ }^{12}$ required close examination when the duties and obligations of bodies responsible for the provision of public sector education were being formulated. The court commented on the need for future legislation inter alia to enable the elimination of discrimination to take place in accordance with a suitable and sensible timescale. By pointing to disparities which will be likely to vary from year to year and which will also be due to factors over which the authorities cannot possibly exercise control, the court has drawn attention to the dilemma which LEAs face at a time when the number of GM schools is increasing.

A further element of flexibility when assessing the performance by LEAs of their statutory duty was suggested when the court observed that it might therefore

8. Education Reform Act 1988, ss. 52 and 79. The Secretary of State has power under s. 81(1) and reg. 24 of the Education (Grant-maintained Schools) (Finance) Regulations 1992 (S.I. 1992/55) to recoup the maintenance grant from the LEA.

9. (1985) 83 L.G.R. 219 (C.A.).

10. Per Woolf LJ in $R$. v. Inner London Education Authority, ex parte Ali (1990) The Times, February 21 (Q.B.D.). See also Meade v. London Borough of Haringey [1979] 2 All E.R. 1016 (C.A.) per Eveleigh LJ at p. 1027 as to the necessity in a state of emergency (a just and reasonable excuse) to close schools for a while in order to achieve the end of making education available in accordance with the statutory duty. 11. (1992) The Times, October 27 (C.A.).

12. See note 91 , infra. 
be right to provide that unlawful discrimination could only be proved if over a period a pattern of discrimination could be established.

\section{LEAs AND A FUNDING AGENCY FOR SCHOOLS}

The Government intends to create a Funding Agency for Schools (the 'FAS'), sharing with LEAs and ultimately taking over the duty to provide sufficient secondary and primary school places in the area when $75 \%$ of secondary (or primary) pupils in the LEA are in GM schools; ${ }^{13}$ to ". . . ease the transition to grant-maintained status" (i.e., encourage schools to opt for GM status); ${ }^{14}$ and, in the course of a move towards unitary local authorities, to see LEAs increasingly as 'enablers' (securing provision for services) rather than 'providers' of services. ${ }^{15} \mathrm{It}$ will be interesting to see whether pressure from LEAs and other bodies for the entry point for the FAS to be raised to a minimum of 50 per cent, or (as proposed, for example, by the National Association of Head Teachers in their response to the White Paper) ${ }^{16}$ for there to be a single changeover point transferring responsibility for the provision of school places to the FAS at that level, results in any change to the current proposal. ${ }^{17}$

\section{0-1992: THE SCHEME OF THE LEGISLATION}

\section{The Education Act 1980}

Although wide-ranging in its reforms, ${ }^{18}$ it is arguable that for current purposes the most significant provisions of the Education Act 1980 (the '1980 Act') are contained in sections 6 to 9 and Schedule 2, enabling parents to express a preference for a school and providing for appeals against a decision on the admission of a child to a school. The 1980 Act uses the word "preference", whereas recently the word "choice" has been used (arguably for political purposes), both in the Parent's Charter ${ }^{19}$ and the Education (Schools) Act 1992.20 It signalled the 'market' approach by the Conservative Government, in which parents were destined to play a significant role, in the first instance by promoting competition between schools by the exercise of a 'preference'.

Chapter 5 of the 1992 White Paper envisages an increasing responsibility at school level for arranging school admissions. GM schools and LEAs will be

\section{Education Bill 1992, Part I.}

14. Cm. 2021, 1992, Ch. 7, pp. 33 et seq..

15. Ibid., Ch. 6, paras. 2, 3 and 5 .

16. National Association of Head Teachers' Response to the Secretary of State's White Paper 'Choice and Diversity', September 1992, Ch. 3, para. 9.

17. Education Bill 1992, cl.7(4) and Sch. 2.

18. For example, school government; admissions to schools; school attendance orders; establishment and alteration of schools; assisted places at independent schools; school meals; nursery education.

19. 'The right to choose' is emphasised at pp. 8 and 9, although the Parent's Charter later states (correctly) that ". . . you have the right to say which school you prefer" (DES emphasis).

20. S.16(3) - see n. 58 infra. 
expected to consider whether joint arrangements to co-ordinate admissions would help reduce delay and uncertainty for parents, but LEAs will continue to have final responsibility to ensure that all children attend school or are otherwise suitably educated. ${ }^{21}$

\section{The Education Act 1981}

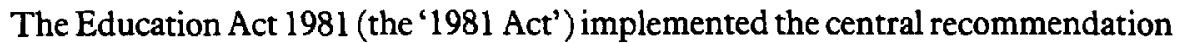
in the Report of the Warnock Committee in 1978 (Special Educational Needs), ${ }^{22}$ with the result that instead of defined categories of 'handicap', children have "special educational needs" (SEN) ${ }^{23}$ if they have a "learning difficulty" 24 which calls for "special educational provision" 25 to be made for them. ${ }^{26}$ At the heart of the 1981 Act is the object that children, including those in GM schools, ${ }^{27}$ who have special educational needs shall receive a suitable education, so far as possible in an ordinary school (the policy of integration).$^{28}$ For children with special educational needs assessed under section 5 of the 1981 Act and for whom the LEA are of the opinion that they should determine the special educational provision that should be made, the LEA must make and maintain a Statement of those needs under section 7 and arrange the special educational provision specified in the Statement, unless a parent has made suitable arrangements. There are rights of appeal under section 8 to an appeal committee (which has only limited powers) and to the Secretary of State.

According to paragraph 15 of DES Circular 22/89, since the implementation of the 1981 Act attention has tended to focus on the two per cent of the school population who have Statements under section 7 , in some areas drawing attention away from the larger group, for whom none the less LEAs and school governors have duties under the Act.

In response to widespread concern as to the failure by LEAs fully to implement the 1981 Act (that failure being expressed cogently by the Audit Commission) ${ }^{29}$ and after consultation, ${ }^{30}$ the Government has responded by proposing to repeal and re-enact the 1981 Act almost entirely. ${ }^{31}$ Clauses 143-145 of the 1992 Bill reflect the policy of integration of children with learning difficulties in ordinary schools so far as possible. LEAs will retain their responsibilities for assessments

21. Education Act 1944, ss. 7 and 8, read with the Education Bill 1992, cl.7.

22. Cmnd. $7212,1978$.

23. Education Act 1981, s.1(1) (emphasis added).

24. Ibid., s.l(2)

25. Ibid., s.1(3)

26. The Warnock Report estimated that up to $20 \%$ of school children would have a special educational need requiring some additional provision at some stage during their school life.

27. Education Reform Act 1988, s. 100.

28. Education Act 1981, s. 2(2).

29. Getting in on the Act - Provision for Pupils with Special Educational Needs: The National Picture, a joint report by The Audit Commission and HM Inspectorate of Schools (HMSO, 1992).

30. Special Educational Needs - Access to the System (DFE, 15 July 1992).

31. Education Bill 1992, Part III and Schs. 8 and 9. 
and Statements under the 1981 Act. ${ }^{32}$ The Secretary of State shall issue, and may from time to time revise, a code of practice giving practical guidance in respect of the discharge by LEAs of their functions under this Part of the proposed Act. ${ }^{33}$ Among the more significant reforms, parents will have the right to express a preference for a particular ordinary or special maintained school for their child; ${ }^{34}$ and Special Educational Needs Tribunals will be established to determine all appeals. ${ }^{35}$ None the less, there are well-informed reservations as to whether the current proposals for reform of the 1981 Act are sufficient, ${ }^{36}$ not least in respect of special educational provision for the estimated 18 per cent of non-statemented children, the absence of legislation as to what information should be specified in a Statement, and the practical operation of regional Tribunals.

\section{The Education (No. 2) Act 1986}

The Education (No. 2) Act 1986 (the ' 1986 Act') is primarily concerned with school government and the composition of the governing bodies of schools. Section 1 requires every school to have an Instrument of Government (its constitution) and Articles of Association (regulating the conduct of the school). The 1986 Act marks a pronounced change in the roles and rights of governors, the LEA and parents respectively. Parent and LEA governors are given equal representation with LEA ${ }^{37}$ and the theme of accountability is emphasised by the requirement that governors shall report annually to parents ${ }^{38}$ and hold an annual meeting with parents. ${ }^{39}$ Links with the local business community are emphasised by virtue of the provisions as to co-opted governors under section 6 .

The LEA's control over the curriculum is diluted, first by section 18 , under which the governing body can determine how the IEA's secular curriculum shall be modified to meet the particular needs of a school, and secondly by provisions inter alia to secure balanced treatment of political issues ${ }^{40}$ and to ensure that sex education shall, so far as reasonably practicable, be ". . . given in such a manner as to encourage ... pupils to have due regard to moral considerations and the value of family life." ${ }_{41}$ The issue of discipline is addressed (providing for exclusion and reinstatement of pupils and appeals). ${ }^{42}$

Under section 42 , the governors have control of the use of school premises

32. Ibid., cl. 147.

33. Ibid., cls. 140 and 141.

34. Ibid., cl. 149 and Sch. 9, paras. 3 and 4.

35. Ibid., cls. 150-154.

36. E.g., Putting Right the 1981 Education Act: Eighteen Further Amendments by the Independent Panel for Special Education Advice (IPSEA - September 1992).

37. Education (No. 2) Act 1986, s. 3(2)-(5); s. 4(2).

38. Ibid., s. 30.

39. Ibid., s. 31 .

40. Ibid., s. 45.

41. Ibid., s. 46.

42. Ibid., ss. 22-28. 
outside school hours (subject to provisos). In general terms the 1986 Act as a whole was the precursor to the major reforms introduced two years later.

\section{The Education Reform Act 1988}

Although the Education Reform Act 1988 (the ' 1988 Act') effects fundamental reforms, these are in a sense developments based on the foundations laid by the previous legislation, relatively little of which is repealed or amended. Part I of the 1988 Act legislates for Schools (whereas Part II deals with Higher and Further Education, which are not within the scope of this article). The three substantial innovations are: (i) the introduction of a National Curriculum; (ii) delegation of responsibility to schools for their budgets; and (iii) provision for schools to acquire grant-maintained (GM) status.

The National Curriculum was introduced by Chapter I of Part I of the 1988 Act, which also provides for the assessment and testing of pupils in maintained schools against attainment targets at ages 7, 11,14 and 16. Chapters II and III provide for admission of pupils up to the limit of a school's capacity and for delegation of a school's 'budget share', implementing Local Management of Schools (LMS) by governing bodies and empowering them to appoint and dismiss staff from their school.

The method for acquiring and the consequences of GM status for schools, funded by a grant from the Secretary of State, ${ }^{43}$ is dealt with under Chapter IV of Part I. The procedure requires two resolutions by the governors and ballot(s) of the parents, and publication of the proposal for the acquisition of $G M$ status, in accordance with sections 60 to 63 of the 1988 Act. The 1988 Act also provides, inter alia, for the powers and conduct of the governing body, transfer of property and staff, finance, admissions, religious education, control over alteration and change of site, discontinuance, winding up and disposal of property.

City Technology Colleges and Colleges for the Technology of the Arts may be established under Part I, Chapter V, and under section 105 the Secretary of State may contribute towards their establishment and running.

The 1992 White Paper made it clear that the Government intended to increase the number of GM schools ${ }^{44}$ and to require LEAs to increase delegation of their budgets to other schools under LMS..$^{45}$ A single new body, the School Curriculum and Assessment Authority, will replace and combine the functions of the National Curriculum Council and the Schools Examination Council. ${ }^{46}$ It appears that to a considerable extent the Government is relying upon schools to opt for GM status, whereas the credibility of that policy has been questioned with reference to resources. On the one hand, it is said that GM status must confer a financial

43. Education Reform Act 1988, s. 52.

44. Ch. 7, pp. 33 et seq..

45. Ch. 6, para. 3 .

46. Education Bill 1992, cls. 214-218, with provision for Wales under cls. 219-223. 
benefit, because the political imperative is to see the drive for GM status to succeed; ${ }^{47}$ on the other hand, funding is likely to be constrained across the board in the current economic climate, a situation which is not made easier for schools when they attempt to assess the advantages of GM status and are presented with differing sets of figures from the DFE and the Chartered Institute of Public Finance and Accountancy. ${ }^{48}$ Part II of the 1992 Bill repeals and substantially re-enacts the provisions of the 1988 Act relating to GM schools (and in particular Chapter IV of Part I of the 1988 Act), but with a significant change contained in clause 17 of the 1992 Bill, which is designed to facilitate a vote by parents as to whether or not a school should apply for GM status by limiting the statutory procedure to one (rather than two) prior resolutions by that school's governors.

\section{The Education (Schools) Act 1992}

The purpose of the Education (Schools) Act 1992 (the '1992 Act') was to revolutionise the method of inspection of schools and to provide a standard against which to measure their performance.

\section{Inspection of schools}

The present regional structure will be radically changed in the case of secondary schools with effect from September 1993 and primary and special schools from September 1994. Under the 1992 Act, Chief Inspectors (HMCI) and Inspectors of Schools (HMI) are appointed by Order in Council for England and Wales respectively, ${ }^{49}$ administered by the Office for Standards in Education (OfStEd). The general duties of HMCI are to keep the Secretary of State informed as to the quality of education and the educational standards achieved in schools; whether financial resources made available to schools are managed efficiently; and the spiritual, moral, social and cultural development of pupils at school. ${ }^{50}$ They also have, inter alia, advisory functions and specific duties to set up and maintain a register of inspectors; to give guidance to HMI and review the system of inspecting schools; and to promote efficiency of inspections by encouraging competition in the provision of services by registered inspectors. ${ }^{51}$ An inspection team must include at least one member without personal experience in the

47. The Government may have to accept an increase overall of expenditure on education in order to protect schools which might be potential losers on acquiring $G M$ status.

48. The difference is in the analysis of the finances of LEAs which have exceeded their education standard spending assessment for 1991-92. Under new financial arrangements, schools in those LEAs may be better off financially by deciding not to apply for GM status (The Times Educational Supplement, August 14, 1992).

49. Education (Schools) Act 1992, s. 1 (England) and s. 5 (Wales).

50. Ibid., s. 2(1).

51. Ibid., s. 2 generally and s. 2(3) in particular. In the case of an inspection under s. 9, before entering into any arrangements for an inspection, the Chief Inspector shall, after consulting the appropriate authority for the school concerned as to the tender specification, invite tenders from at least two registered inspectors at arm's length from each other - s. 9(7) and Sch. 2, para. 2. 
management of any school or the provision of education in any school (otherwise than as a governor or in any other voluntary capacity) and whose primary function on the team is not that of providing financial or business expertise. ${ }^{52}$

The LEA may provide services for the inspection of schools whether or not they are maintained by that LEA, ${ }^{53}$ in such a way as can reasonably be expected to recover the full cost by way of charges made by the LEA for its services. ${ }^{54}$ Separately, the LEA may inspect a maintained school for a specific purpose..$^{55}$

Schedule 2, para. 9 provides for reports to be made by the registered inspector and for such reports to be made available to members of the public and for such steps to be taken as are reasonably practicable to secure that every parent of a registered pupil at the school receives a copy of the summary as soon as is reasonably practicable.

\section{Information about schools}

The Secretary of State has power to make regulations under section 16 of the 1992 Act requiring governing bodies of maintained schools (and proprietors of independent schools $)^{56}$ to provide information, including destinations of pupils leaving a school..$^{57}$ Such information is intended to be such as is likely to assist parents in choosing schools for their children (emphasis added); ${ }^{58}$ to increase public awareness of the quality of education at and educational standards of schools; and to assist in assessing the efficiency of management of the financial resources of schools. This is the basis for controversy as to the validity of data as to examination results without taking account of the 'value added' according to the socioeconomic background of the pupils and other factors. ${ }^{59}$

From the autumn term 1992, all maintained schools have had to publish their record of "unauthorised pupil absence" (i.e. truancy) in their prospectuses and annual reports and from 1993 this information will be included in performance tables published locally in respect of all schools. ${ }^{60}$

\section{'Failing' schools}

Inspection reports are intended to identify "schools at risk", and the Secretary of State will have the ultimate power to appoint an 'Education Association' to take over the management of an 'at risk' school or groups of schools. The Education

52. Ibid., ss. 9(7) and Sch. 2, para. 3(2).

53. Ibid., s. 14(1)-(3).

54. Ibid., s. 14(4).

55. Ibid., s. 15.

56. Ibid., s. 16(9).

57. Ibid., s. 16(2).

58. Ibid., s. 16(3) - see notes 19 and 20 supra.

59. See, e.g., D. Hutchison, Chief Statistician to the National Foundation for Educational Research, School Records - Making Sense of School Results (1991). In response to criticisms of results from raw data, the Government is consulting as to publication of results which reflect 'value added' by schools. 60. Cm. 2021, 1992, Ch. 5, para. 8. 
Association will consist of a chairman and typically some five other part-time members appointed by the Secretary of State and the Education Association has, in relation to each of the schools for which it is responsible, the powers and funding of a GM body. ${ }^{61}$

\section{SUBORDINATE LEGISLATION AND DES/DFE CIRCULARS}

While the subordinate legislation which is still in force dates back to 1944, the substantial flow of regulations affecting schools commenced (not surprisingly) from 1980. Among many possible examples of the most significant statutory instruments are those relating to information made under the $1980 \mathrm{Act}^{62}$ to special educational needs under the $1981 \mathrm{Act}^{63}$ to school government under the 1986 (No. 2) Act; ${ }^{64}$ and to $G M$ finance ${ }^{65}$ and the national curriculum ${ }^{66}$ under the 1988 Act.

The number of Departmental Circulars (and Administrative Memoranda) from the DES (now the DFE) and the Welsh Office, both current at 1 January 1979 and issued thereafter, is (to say the least) substantial. The standard disclaimer as to the status of a circular reads: "The guidance in this circular does not constitute an authoritative legal interpretation of the [Act] or the [Regulations]: that is a matter for the courts." None the less, the circular is highly influential, and it is arguable that for the LEA to disregard guidance in a circular may amount to the LEA acting so unreasonably or irrationally or unfairly as to justify prima facie an application for judicial review. Among the better known and recent Circulars are No. 11/88 as to admission of pupils to county and voluntary schools under the 1980 and 1988 Acts; No. 22/89 and Addendum dated 10 March 1992 as to procedures for assessments and statements of special educational needs under the 1981 Act and consequential Regulations; Nos. 7/88 and 7/91 as to local management of schools; and No. $10 / 88$ as to grant-maintained schools.

One recent example of the status of circulars is the Addendum to Circular 22/89 dated 10 March 1992, which made revisions to existing guidance in the light both of recent judicial decisions, notably $R$. v. Secretary of State for Education and Science, ex parte $E,{ }^{67}$ and legislation. In spite of the fact that circulars only

61. Education Bill 1992, Part V.

62. Education (School Information) Regulations 1981 (S.I. 1981/630); Education (Information on School Examination Results) (England) Regulations 1991 (S.I. 1991/1265).

63. Education (Special Educational Needs) Regulations 1983 (S.I. 1983/29); Education (Special Educational Needs) (Amendment) Regulations 1990 (S.I. 1990/1524); Education (Special Educational Needs) (Approval of Independent Schools) Regulations 1991 (S.I. 1991/449).

64. Education (School Government) Regulations 1989 (S.I. 1989/1503).

65. Education (Grant-maintained Schools) (Finance) Regulations 1992 (S.I. 1992/555).

66. Regulations relate to Assessment Arrangements; Attainment Targets and Programmes of Study; and Exceptions.

67. [1992] 1 F.L.R. 377 (C.A.). 
constitute 'guidance', in practice they determine the day-to-day implementation of education policy. ${ }^{68}$

\section{COMPLAINTS TO SECRETARY OF STATE}

In addition to powers conferred by legislation as to specific matters, the Secretary of State can exercise two significant powers under section 68 or section 99 of the 1944 Act, either on his own initiative or as a result of a complaint to him.

If the Secretary of State is satisfied, either on a complaint by any person or otherwise, that the LEA or the governors of schools (county, voluntary or GM) or other specified institutions have acted or are proposing to act unreasonably, under section 68 the Secretary of State can give such directions as appear to him to be expedient. It has been held that the courts can enforce compliance with a bona fide direction by way of an order of mandamus. ${ }^{69}$ Section 99 empowers the Secretary of State, either on a complaint by any person or otherwise, to give directions where the LEA or school governors are in default by virtue of a failure to discharge their statutory duty; the section specifically provides that any such direction is enforceable, on an application made on behalf of the Secretary of State by mandamus.

These sections have not been regarded as providing a suitable means of avoiding litigation in order to have a grievance investigated and rectified due to the time which it takes for the DFE to investigate a complaint and for the Secretary of State to reach a decision. The position is aggravated if a failure to make a complaint to the Secretary of State risks invalidating an application for judicial review by virtue of the argument that complaints under the 1944 Act may be a means of appeal which must be first used before making such an application. It is also contrary to the principle that there should be the minimum of delay in reaching decisions when the upbringing of a child is at issue, ${ }^{70}$ a factor which may encourage the courts to intervene by way of judicial review where the education of a child is at issue. It also remains to be seen whether a reorganisation within the DFE to deal with a recent and substantial increase in the number of complaints by parents will result in a more prompt and effective remedy for parents under the 1944 Act.

\section{THE OMBUDSMAN AND THE LOCAL OMBUDSMAN}

A complaint of maladministration against the DFE can be investigated by the Parliamentary Commissioner for Administration (the Ombudsman) and a

68. See The Law of Education 9th ed. (Butterworths), Division E - Circulars, Circular Letters and Administrative Memoranda.

69. Secretary of State for Education and Science v. Tameside Metropolitan Borough Council [1977] A.C. 1014 (H.L.).

70. Children Act 1989, s. 1(2). 
complaint of maladministration against the LEA can be investigated by the Commissioner for Local Administration (the Local Ombudsman). Parents are increasingly making complaints to the Local Ombudsman in respect of actions or omissions by the LEA, but it is regrettable that where there is a finding of maladministration causing an injustice that decision is not enforceable and is on occasions ignored by a local authority. It is a measure of the importance of the Local Ombudsman's decisions in respect of the law of education that they are now reported on a regular basis. ${ }^{71}$

\section{THE GROWTH OF JUDICIAL REVIEW IN ENGLAND AND WALES}

Among lawyers who specialise in the law of education there is concern that voluntary organisations who advise parents may come to see judicial review as a remedy of first rather than last resort and generally that there may be a temptation to make applications which are precipitate or inappropriate.

It is essential that clients should be advised that judicial review is not the same as an appeal. An Act of Parliament may grant decision-making powers or discretions and impose duties upon a decision maker, who may be an individual, a body of persons or a corporation. The statute may or may not provide machinery for an appeal against that decision and the appellate process. ${ }^{72}$ Once the decision has been made and any appeal process has been exhausted, the merits of the decision are not open to judicial review. It is usually necessary for the applicant to have used all available appeal procedures before judicial review can even be considered.

Clients also find it difficult to accept that in proceedings for judicial review the court is concerned only to see whether the decision-maker has contravened the law by acting in excess of the powers which Parliament has confided in him ${ }^{73}$ and that the function of the court is therefore a limited supervisory one. ${ }^{74}$ Before initiating proceedings for judicial review, care must be taken to assess whether what is being sought is not an oblique appeal, ${ }^{75}$ and that prima facie there is a ground within the three heads which Lord Diplock suggested that administrative action is subject to judicial review - 'illegality'; 'irrationality' (in the sense of being so unreasonable that no reasonable authority would have come to that particular conclusion); and 'procedural impropriety'. ${ }^{76}$

71. See, e.g., Education and the Law (Longman).

72. R. v. Independent Television Commission, ex parte T.S.W. Broadcasting Ltd. (1992) The Times, March 30 (H.L.).

73. Associated Provincial Picture Houses Ltd. v. Wednesbury Corporation [1948] 1 K.B. 223 (C.A.), per Lord Greene MR at p. 233.

74. Kent v. University College London (1992) The Times, February 18 (C.A.).

75. R. v. Secretary of State for Education and Others, ex parte Banham (1992) The Times, March 9 (Q.B.D.).

76. Council of Civil Service Unions and Others v. Minister for the Civil Service [1984] 3 W.L.R. 1174, at p. 1196 (H.L.). When suggesting the grounds for judicial review (illegality, irrationality and procedural impropriety), Lord Diplock did not rule out the addition of further grounds, ". . particularly the 
Practitioners are often faced with a major problem when a client has allowed time to elapse before taking legal advice as to an administrative decision. An application must be made promptly and in any event within three months from the date when the grounds for application first arose unless the court considers that there is good reason for extending the period for applying. ${ }^{77}$ An application for legal aid may have to be made on an emergecy basis within the time limit.

There is a further complication which has to be explained to a client, namely that success in judicial review proceedings may be an illusion, because the court has discretion whether or not to make an order. There may be proven procedural impropriety, but the court may decide that it did not affect the outcome and that no order should be made. This recently occurred when the court held that a selection panel of governors which had been constituted to appoint a headteacher should not operate with less than its complement of numbers, but on the facts the judge refused to grant relief. ${ }^{78}$ Another example of the illusion of success occurs when one party obtains an order by the court that there has been procedural impropriety, whereupon the other party repeats the decision-making process, the second time properly, so that the original decision in effect is reinstated.

Against that background, various issues which have been the subject of applications for judicial review are now considered.

\section{Procedural errors - removal of governors}

The power of removal now exists by virtue of section 8(5) of the 1986 Act. This issue was considered in Inner London Education Authority v. Brunyate and Another, ${ }^{79}$ when the House of Lords unanimously held (per Lord Bridge of Harwich) that ". . . individual governors, so long as they hold office as such, have both the right and the duty to exercise the function of their office independently in accordance with their own judgment. It follows implicitly ... that the power of removal cannot be exercised in a way that would amount to a usurpation of the governors' independent role." 80

Governors who are appointed by the LEA are not, therefore, delegates and cannot be required to vote on any particular issue as the authority wishes. ${ }^{81}$ In $R$. v. Westminster Roman Catholic Diocese Trustee, ex parte Andrews ${ }^{82}$ the Court of Appeal decided that it was bound by Brunyate and therefore concluded that the removal of two governors who would not support the trustee's scheme for reorganisation of a school had not been a valid exercise of the trustee's powers.

possible adoption in the future of the principle of 'proportionality' which is recognised in the administrative law of several of our fellow members of the European . . . Community. ..."

77. R.S.C. Order 53, Rule 4.

78. R. v. Birmingham City Council, ex parte McKenna (1991) The Times, May 16 (Q.B.D.).

79. [1989] 1 W.L.R. 542 (H.L.) (when S. 21(1) of the Education Act 1944, now repealed and replaced by s. $8(5)$ of the Education (No. 2) Act 1986, was at issue).

80. Ibid., at p. 547.

81. Ibid., at p. 548 .

82. (1989) The Independent, July 27 (C.A.). 
The 'political proportionality' principle

By contrast, in $R$. v. Warwickshire County Council, ex parte Dill-Russell and Another ${ }^{83}$ the Court of Appeal upheld a decision by the Divisional Court that a council can (by removal under section 8(5) of the $1986 \mathrm{Act}$ ) replace school governors after a county council election in order to facilitate better synchronisation of appointments of governors and county council elections. Warwickshire's intention had not been to abrogate the independence of governors (as was the case in Brunyate) but rather to preserve political proportionality on governing bodies, corresponding with the representation of political parties on the council.

\section{The relevance of statutory consultation}

The Divisional Court has held that a failure to consult, and the conjoined failure to consider the education implications of a LEA's scheme to withdraw a school's site from the scope of the statutory transfer to the Education Assets Board, ${ }^{84}$ vitiated the decisions of the urgent matters sub-committee, and of the policy and resources committee in $R$. v. Tameside Metropolitan Borough Council, ex parte Governors of Audenshaw High School and Another ${ }^{85}$ The LEA's bona fide scheme to withdraw the site from the scope of the statutory transfer if the school obtained grantmaintained status fell on this single point of failure to consult.

\section{School admissions}

The House of Lords recently refused leave to appeal against the decision in $R$. v. Bromley London Borough Council, ex parte $C^{86}$ that there is a clear duty on the LEA not in any way to differentiate between applicants living within the LEA's area and those living outside it when considering applications for admission, following the decision of the Court of Appeal in $R$. v. Shadow Education Committee of the London Borough of Greenwich, ex parte the Governors of John Ball Primary School and Others. ${ }^{87}$

In deciding Greenwich, the Court of Appeal applied the rules of statutory interpretation. Lloyd LJ also identified what he described as ". . . the seeds of a possible theoretical difficulty" if there was an influx of children to Greenwich, but he decided that on the particular evidence there was little practical difficulty. ${ }^{88}$ Farquarson LJ considered that the so-called 'floodgates' argument (as to numbers of pupils likely to cross the border between the adjacent LEAs) did not have much reality.

83. (1990) The Times, December 7 (C.A.).

84. Education Reform Act 1988, ss. 74 and 198.

85. (1990) The Times, June 27 (Q.B.D.).

86. [1992] 1 F.L.R. 174 (Q.B.D.).

87. (1990) 88 L.G.R. 589 (C.A.).

88. Ibid., at p. 598 . 
By contrast, in Bromley, Watkins LJ commented that for a LEA to provide an efficient education as required by sections 7 and 8 of the Education Act 1944, in the light of the interaction between those sections and section 6 of the 1980 Act (imposing parental preferences), was 'painfully difficult', especially where there was oversubscription. Watkins $\mathrm{LJ}$ and Owen J saw much practical difficulty and it did not surprise them to learn that representations had been made to the Secretary of State to have the law changed. ${ }^{89}$

Greenwich also bound the Queen's Bench Divisional Court in R. v. Royal Borough of Kingston upon Thames, ex parte Kingwell ${ }^{90}$ in which Mr. Kingwell was considerably aggrieved that, long after he had moved into the Borough so that his daughters could be educated at a selective, single-sex grammar school (and he had paid his community charge to the Borough), the Borough as LEA changed its admissions policy in the light of the decision in Greenwich, giving his daughters no priority over applicants living outside the LEA's area. The case illustrates the effect of the threat of or an actual application for judicial review, because less than a month after $\mathrm{Mr}$. Kingwell commenced judicial review proceedings, the admissions limit of his preferred school was increased (against opposition) and his elder daughter was offered a place. That did not, however, deter him from pursuing his application to have the new admissions policy declared unlawful, although his challenge was unsuccessful.

The primacy of parental preference was also demonstrated in $R$. v. Cleveland County Council and Others, ex parte Commission for Racial Equality, ${ }^{91}$ when the Court of Appeal held that the mandatory duty to comply with a parental preference imposed by section 6(3) of the 1980 Act was not qualified by section 18 of the Race Relations Act 1976. The child was of mixed race and the mother was distressed by the suggestion that her motives in seeking a transfer for her daughter to another school were in any way racially governed. In any event, the Court of Appeal decided that the transfer of the child was not an act of segregation on racial grounds.

On the other hand, in $R$. v. Governors of the Bishop Challoner Roman Catholic Comprehensive Girls'School and Another ${ }^{92}$ the House of Lords upheld the decision of the Court of Appeal that a voluntary aided school's admissions policy of giving preference to Christians, preferably Catholics, was lawful under the exception in section 6(3)(a) of the 1980 Act when the school was oversubscribed and had to have an admissions policy.

\section{Children with special educational needs}

The procedures under the 1981 Act are sufficiently complex for the Court of

89. [1992] I F.L.R. 174, at p. 181 (Q.B.D.).

90. [1992] 1 F.L.R. 182 (Q.B.D.).

91. (1992) The Times, August 25 (C.A.). Para. 49 of DES Circular 11/88 reminds LEAs and governors of the Race Relations Act 1976 and the Sex Discrimination Act 1975.

92. [1992] 1 W.L.R. 99 (H.L.). 
Appeal to have acknowledged with appreciation the provision by Counsel for the Secretary of State of a 'flow chart', which was annexed to the transcript of the judgments in $R$. v. Secretary of State for Education and Science, ex parte $E,{ }^{93}$ in which the provision for a child's special educational needs was not adequately specified in the statement made under section 7 of the 1981 Act. Although Part II of the LEA's statement described $\mathrm{E}$ as "experiencing difficulties in literacy and numeracy skills", Part III of the statement dealt only with special educational provision for E's literacy difficulties and failed to mention the numeracy difficulties.

An Addendum dated 10 March 1992 to DES Circular 22/29 (supra) was subsequently issued, clarifying guidance on statutory procedures under the 1981 Act and the form and content of statements, revised to take account of the judgment in Ex parte $E$ and other decisions. ${ }^{94}$

\section{The Secretary of State's quasi-judicial function}

The question has been raised as to the quasi-judicial function of the Secretary of State when considering an application for GM status, while at the same time actively encouraging such applications in line with his party's political policy. $R$. v. Secretary of State for Education and Science, ex parte Avon County Council (No. 2) ${ }^{95}$ established that the Secretary of State is entitled to have a political policy, provided that the machinery of the Act is complied with and the Minister has acted lawfully, because the Minister is accountable to Parliament in respect of his assessment of the best method by which to secure the objects of the legislation. The Secretary of State can properly decide to approve an application by a school for GM status even if such approval will effectively frustrate an LEA's reorganisation scheme.

Ralph Gibson LJ considered that Avon's application was misconceived in so far as it asked the court to intervene in what was, when analysed, a dispute as to educational policy between Avon and the Minister. It was common ground that the approval of GM status for Beechen Cliff would frustrate the re-organisation. Ralph Gibson LJ observed that " . . . [t] he Minister, however, was acting under powers given by Parliament in the Act of 1988. If he was acting lawfully within those powers, there is no purpose in seeking to demonstrate that the proposals put forward by Avon are, in the view of those putting them forward, superior for the purposes of advancing the quality of secondary education for the children of Bath. Parliament did not entrust the making of that judgment to the court but to the Minister who is answerable in respect of his decisions to Parliament." ${ }^{96}$ Nicholls and Mustill LJJ concurred. 


\section{CONCLUSION}

From 1980 to 1992 the emphasis was on legislation, both primary and subordinate, which created a new framework for education in schools and a diminishing role for LEAs. Applications for judicial review increased to a pronounced extent, because the complexity of the new relationships between schools and the Secretary of State and LEAs has inevitably led to questions as to procedures and the legality of decisions made under that legislation.

The 1992 Bill received its second reading on 9 November. Its objectives are formidable - to establish Funding Agencies for schools in England and Wales and to redistribute responsibility for, and the provision of, education at school; to encourage the majority of schools to opt for GM status; to reform the arrangements for children with special educational needs; to amend the law on admissions and school attendance orders; to establish Education Associations for failing schools; and to establish a School Curriculum and Assessment Authority. Extensive regulations will have to be made in order to give effect to the primary legislation.

Doubts have already been raised as to whether the central thrust of Government policy - a substantial increase in the number of GM schools - will be achieved, not only because of questions as to the financial benefits or otherwise, but also due to the lack of any requirement that schools should hold regular ballots of parents on this issue, rather than leaving the initiative primarily with the governing body.

When the 1992 Bill is considered in the context of the Education (No. 2) Act 1986, the Education Reform Act 1988, the Education (Schools) Act 1992 and the Further and Higher Education Act 1992 (which is outside the scope of this article), the scale and pace of reform of the law of education is seen to be exceptional. Demand for advice and representation in this field has expanded dramatically, involving not only lawyers in private practice or employed in the public sector, but also law centres, educational psychologists and a wide variety of charitable organisations. As a result, the law of education is set to become one of the most prominent specialist areas this decade. 